\title{
J.M.Synge (1871-1909)
}

\section{Luasnad, Capa and Laine*}

LUASNAD. The rain is over. Perhaps with the cold of dawn

New winds may come and blow all these clouds away

Across the sea.

CAPA. I see a star, Luasnad.

LUASNAD. There are no stars, the stars are all washed out As dew-drops perish.

CAPA. Look where the teals are crying

Here to the westward.

LUASNAD. Do you rave again

Or are my eyes blasted with all my weeping?

Is it I who am made blind to hope?

CAPA. Where is Laine?

LUASNAD. He is fast asleep. I left him

Bent down beneath a boulder with his wife.

CAPA. Look, look! the clouds have parted!

LUASNAD. I can see it Capa. It is certain

That now the rains will cease.

CAPA. There are The Seven

And there the Pole-star.

1. This text is taken from Ann Saddlemyer's edition of The Plays of J.M.Synge, inciuded in Robin Skelton's edition of The Collected Works of J.M.Synge (Gerrards Cross: Colin Symthe, 1982, vol. III, pp. 194-205). I have included most of her editorial suggestions, and taken the liberty of adding three full stops missing from her edition (pp. 199, 200, 201). For a history of the writing of the play and Synge's sources, see her comments on p. 195. Although apparently incomplete, the text reveals Synge's early interest in mythological subjects. It also contains some indications of Synge's pantheism, and may show his interest in Yeats's ideas about moods being the incarnation of eternal emotions, especially in the last dialogue between Luasnad and Laine's wife, which may be related to Yeats's dramatic poem The Shadowy Waters, published in 1900, and later staged in January 1904. However, there are important differences, mostly stemming from Synge's more realistic and down-to-earth treatment of the characters, which vividly contrasts with Yeats's tendency to idealization. These characteristics, together with the evident pessimism, suggest that Synge's unfinished play should be taken into consideration when analyzing his posthumous tragedy, Deirdre of the Sorrows. Apart from being unpublished in Spanish, the play also has the interest of being a modern interpretation of one of the Irish legends blending native traditions and Christian material, more specifically the biblical story of the deluge, which link the beginnings of Ireland's history to Spain. 


\section{Luasnad, Capa y Laine}

\section{Traducción de Francisco Javier Torres Ribelles}

LUASNAD. Ya no llueve. Quizá con el frío del alba vengan nuevos vientos y se lleven estas nubes por el mar.

CAPA. Se ve una estrella, Luasnad.

LUASNAD. Ya no hay estrellas, han sido barridas por el agua al igual que desaparecen las gotas de rocío.

CAPA. Mira donde gritan las cercetas, ahí al oeste.

LUASNAD. ¿Otra vez deliras o es que tengo desgarrados los ojos de tanto llorar? ¿Soy yo que ya estoy ciego a la esperanza?

CAPA. ¿Dónde está Laine?

LUASNAD. Duerme profundamente. Lo he dejado echado bajo una roca con su esposa.

CAPA. ¡Mira, fíjate! Se han abierto las nubes.

LUASNAD. Ya lo veo, Capa. Seguro que ahora cesarán las lluvias.

CAPA. Ahí está el Carro, y ahí, la Estrella Polar. 
LUASNAD. There look we had lost the North.

CAPA. The wind comes from it, and in this isle of Banba

North winds are dry.

LUASNAD. We may walk through forests

In twenty days, then we will build a curagh

And let this north wind drive us home to Spain.

CAPA. I hear the birds upon the eastern peak.

There is new hope among them for they know

That all these rains are weary.

LUASNAD. If they sing

The dawning cannot linger.

CAPA. In the east

The mists are purple.

LUASNAD. Yesterday

How many mountains could we count at dawn?

CAPA. I marked them out with knots along my belt-

Seven we saw. [A cry of women's voices.] Your wife is still in labour?

LUASNAD. When women do good things they choose a time

That makes it silly. Here the child will die.

\section{[Enter LAINE.]}

LAINE. This woman's cry has roused me and the water

Had reached my ankles!

CAPA. See the sky

Is turning blue above us, we shall live

In spite of all this deluge.

LUASNAD. Let us measure

The movement of the night.

[They go down to the brink and look at some marks on a stone.]

CAPA. The rise out-passes

The width of both my hands - It has passed

So high above my scoring I can only

Make guesses at its measure.

LUASNAD. It is light

And we will clamber up against the sky

To number all the hill-tops that are bare.

LAINE. Pick stones Capa, the hares are hid so thick

Above us in the heather they will starve 
LUASNAD. No te lo decía, fíjate, no sabíamos dónde estaba el norte.

CAPA. De allí viene el viento, y en esta isla de Banba los vientos del norte son secos.

LUASNAD. Podemos atravesar los bosques caminando en veinte días, y después construir una barca y dejar que este viento del norte nos lleve a casa, a España.

CAPA. Oigo los pájaros en el pico del este.

Se les ha renovado la esperanza, porque saben que las lluvias han perdido la fuerza.

LUASNAD. Si cantan, es que se acerca el alba.

CAPA. Por el este las neblinas son violáceas.

LUASNAD. $\quad$ AAyer cuantos montes contamos al amanecer?

CAPA. Los señalé con nudos en mi cinturónSiete vimos. [Se oyen gritos de mujeres.] ¿Aún está de parto tu esposa?

LUASNAD. Cuando las mujeres hacen algo bueno siempre eligen el momento más tonto. Aquí el niño morirá.

\section{[Sale LAINE.]}

LAINE. ¡El grito de esa mujer me ha despertado, y el agua ya me llegaba a los tobillos!

CAPA. Fíjate, el cielo se está haciendo azul encima de nosotros, seguiremos vivos a pesar de este gran diluvio.

LUASNAD. Vamos a medir el cambio de la noche.

[Bajan al borde del agua y miran una piedra que tiene unas señales.]

CAPA. La subida sobrepasa

casi un palmo de mi mano-Está tan por encima de la marca que tengo que adivinar la altura.

LUASNAD. Hay luz, y subiremos hacia el cielo para contar las cumbres aún visibles.

LAINE. Coge piedras, Capa, hay tantas liebres escondidas en el brezo que morirán de hambre, 
And if they starve we perish.

CAPA. All the goats

Will swim straight over from the eastern peak

For it will soon be covered.

LAINE. $\quad$ Look, the sun

We have not seen for near two score days

Is rising.

LUASNAD. Let us feel this warmth, stand quiet.

CAPA. Something moves across the red-gold pathway.

Look on it Laine, I have looked so long

I see green moons about me.

LUASNAD. The sea is filled

With limbs of trees the Liffey broke to pieces

Before the sea engulfed the lakes and streams.

LAINE. I see it Capa, it is high above

The red sea's level.

CAPA. I think it is the curagh

That we first came from Spain in, for the prow

Is bending backward like a man's close hand.

LUASNAD. The east peak is between us; it will stop there.

CAPA. Some god is guiding it for it creeps on, Half turned against the wind.

LUASNAD. The gods but toy

And make their sport to urge out sightless hope.

[The cry of a child is heard on the other side of the peak.]

LAINE. Your child is born Luasnad, and it lives.

CAPA. It is the first man's child has cried on Banba.

LUASNAD. It will be the first dead human body.

Count the hills.

LAINE. Lugdubh,

Craigmoira, Tonagee and Inchavor.

LUASNAD. Three are covered?

LAINE. And the rest are sinking.

CAPA [looks round from the summit]. Our curagh lies against the eastern peak And all the birds are flashing round about us.

LAINE. Their peak will soon sink under. 
y nosotros con ellas.

CAPA. Todas las cabras

se vendrán nadando derechas del pico del este, pues pronto estará cubierto.

LAINE. Mira, el sol, que casi en cuarenta días no hemos visto, sale ahí.

LUASNAD. No os mováis, que nos dé calor.

CAPA. Algo está cruzando su ardiente estela de oro.

Míralo tú, Laine, yo he mirado tanto

que veo lunas verdes por todas partes.

LUASNAD. El mar está repleto de restos de árboles destrozados por la crecida del Liffey antes de que el mar se tragara los lagos y los ríos.

LAINE. Ya lo veo, Capa, está muy por encima de la superficie del rojo mar.

CAPA. Creo que es la barca en la que vinimos de España la primera vez, pues la proa es muy alta y caída hacia atrás, como el puño de un hombre.

LUASNAD. Nos separa de ella el pico del este. Se detendrá allí.

CAPA. Un dios la guía, pues avanza despacio con la amura al viento.

LUASNAD. Los dioses no hacen más que jugar, y se divierten animando esperanzas ciegas.

[Se oye el llanto de un niño al otro lado del pico.]

LAINE. Luasnad, ha nacido tu hijo, y ha nacido vivo.

CAPA. Es el primer hijo de hombre qu'ha llorado en Banba.

LUASNAD. Será el primer cuerpo humano muerto. Cuenta los montes.

LAINE. Lugdubh,

Craigmoira, Tonagee... Inchavor.

LUASNAD. ¿Hay tres cubiertos?

LAINE. Y el agua ya va a cubrir los otros.

CAPA [desde la cumbre mira alrededor]. Nuestra barca la ha parado el pico de oriente, $\mathrm{y}$ todas las aves vuelan veloces en torno nuestro.

LAINE. El monte en que viven pronto estará bajo el agua. 
CAPA. In the west

The rains continue.

WIFE OF CAPA. Your wife is dead Luasnad

And I have brought your infant. See, a boy.

LAINE. If the goats swim over from the eastern peak

Their milk will feed him.

WIFE OF CAPA. I have wrapped him warm

With your dead wife's green mantle. Are we saved

Now that the rains are over and the air is warm?

CAPA. It was late winter when the rains began,

Now it is early summer. Wind may rise-

[Wild cry on the hill.]

WIFE OF CAPA. It is the wife of Laine who laments

The wife of Luasnad.

CAPA. Goats are swimming and

Our curagh floats here westward with the tide.

LAINE. It will reach us if no north winds waken.

There is a ripple on our left hand side,

The prow is turning. Come down and we may reach it.

WIFE OF CAPA. I leave your child Luasnad, it is sleeping

And I would wail its mother. [Puts it down beside LUASNAD and goes down.]

CAPA [below]. The goats have seen us

And passed on in the sea.

LAINE. The wind is gaining,

The prow is turning down against the south -

[Runs down into the water, falls and climbs out again.]

The water is not salted, taste it Capa. [They drink.]

LUASNAD. The gods are jesting with them.

[Crying from the women.]

CAPA. Still it rises.

LUASNAD. I think it is the end of all men's life

For I am sick with hoping. While they talked

I saw two great green wood-birds flown from Spain

Pass from the eastern peak.

[LAINE and CAPA pass, chasing hares.]

CAPA. Strike it Laine. 
CAPA. Por el oeste

siguen las lluvias.

ESPOSA DE CAPA. Tu esposa ha muerto, Luasnad, y aquí tienes la criatura. Mira, es un chico.

LAINE. Si las cabras del pico del este vienen hasta aquí, podrá alimentarse de la leche.

ESPOSA DE CAPA. Lo he liado bien calentito en el manto verde de tu esposa muerta. ¿Estamos salvados?

Las lluvias han acabado y el aire es cálido.

CAPA. Se estaba terminando el invierno cuando empezaron las lluvias, y ahora ya es verano. Quizá se levante viento-

[Se oye un grito desgarrado en el monte.]

ESPOSA DE CAPA. Es la esposa de Laine, que llora a la de Luasnad.

CAPA. Las cabras están en el agua, y nuestra barca viene por el este con la marea.

LAINE. Llegará hasta aquí, si no se forma viento del norte.

El agua está rizada a nuestra izquierda, la proa está girando. Baja aquí, a ver si la cogemos.

ESPOSA DE CAPA. Dejo aquí a tu hijo, Luasnad, está dormido, y quiero llorar a su madre. [Lo deja en el suelo junto a LUASNAD y desciende.]

CAPA [desde abajo]. Las cabras nos han visto, y pasan de largo.

LAINE. El viento va aumentando, la proa se ha puesto mirando al sur-

[Se mete en el agua corriendo, se cae, y sale con dificultad.]

El agua no es salada, pruébala Capa. [Beben.]

LUASNAD. Los dioses se burlan de ellos.

[Se oyen lamentos de las mujeres.]

CAPA. Continúa subiendo.

LUASNAD. Creo que es el fin de toda vida humana, pues ya no puedo de tanto esperar. Mientras hablaban vi dos grandes pájaros verdes venidos de España pasar volando desde el pico de oriente.

[Pasan LAINE y CAPA persiguiendo liebres.]

CAPA. Dale, Laine. 
LUASNAD. And in the foam while Capa gazed at sea

I saw a sick man's crutches girt with hide.

LAINE. The wind is rising -there is spray around

The eastern peak-

LUASNAD. What was the eastern peak.

LAINE. Before this white sun and this dry north wind

These waters cannot linger.

LUASNAD. In a storm

These rocks would tumble.

CAPA. There is no sign of storm.

LUASNAD. You did not hear the gannets all last night Fly past us from the north?

LAINE. I dreamed of Spain

And of the first grey morning when we saw

These hills of Banba.

CAPA. I dreamed nine babes

Were born in one bearing by my wife.

[The two women carry in the dead body of LUASNAD's wife.]

WIFE OF LAINE [sings.] We steered with star of Spain

To come with worlds that wane.

WIFE OF CAPA. Where winds are wailing.

WIFE OF LAINE. We left the scent of Spring

Upon your grave to sing.

WIFE OF CAPA. Where clouds are sailing.

CAPA. The wind is turning west.

LAINE. The sunlight scorches,

There is no shadow on this spire of stone.

[A gust of wind carries the cloth from the face of the dead woman into the sea.]

LUASNAD. The winds increase.

WIFE OF LAINE. Are you frightened, Luasnad?

I think the seas will lessen day by day.

LUASNAD. You hope our bones may win a space to bleach?

CAPA. He is gloomy for his wife has perished

And his man-child may follow.

[A wave breaks on the rock.] 
LUASNAD. Y en la espuma, mientras Capa miraba el mar, vi las muletas de piel de un enfermo.

LAINE. El viento aumenta-las olas salpican la cumbre del este-

LUASNAD. Lo que fue cumbre del este.

LAINE. Ante este sol blanco y este viento seco del norte, las aguas no pueden continuar.

LUASNAD. En un temporal estas rocas se desprenderían.

CAPA. No hay signos de tempestad.

LUASNAD. ¿Es que no has oído toda la noche a los alcatraces que pasaban volando hacia el sur?

LAINE. He soñado con España y con la mañana gris en que vimos por vez primera estos montes de Banba.

CAPA. Yo he soñado que nueve niños nacían en un sólo parto de mi esposa.

[Las dos mujeres salen trayendo el cadáver de la esposa de LUASNAD.]

ESPOSA DE LAINE [canta.] Navegamos con la estrella de España para venir a mundos que menguan.

ESPOSA DE CAPA. Donde se lamentan los vientos.

ESPOSA DE LAINE. Dejamos que el aroma de la primavera cante sobre tu sepultura.

ESPOSA DE CAPA. Donde navegan las nubes.

CAPA. El viento está rolando al oeste.

LAINE. El sol reseca, no hay ni pizca de sombra en esta aguja rocosa.

[El paño que cubre la cara de la muerta se lo lleva una ráfaga de viento, y cae al mar.]

LUASNAD, Los vientos crecen.

ESPOSA DE LAINE. ¿Estas asustado, Luasnad?

Creo que las aguas menguarán día a día.

LUASNAD. ¿Te crees que nuestros huesos tendrán un lugar donde blanquear?

CAPA. Está sombrío porque su esposa ha muerto, y porque quizá la siga este niño.

[Una ola rompe en la roca.] 
LUASNAD. There is no gloom

Beyond this gloom that hems the shroud of all men.

WIFE OF LAINE. Is there a war among the gods and have

The sea gods conquered?

LUASNAD. There is no war.

The gods work only to gain peace from prayer.

[Another wave breaks.]

CAPA. Speak no more evil Luasnad, it may harm us.

LUASNAD. I have ceased to pray, and there is nothing

More apt than prayer to anger.

WIFE OF LAINE. Say to them

If they will take this water from the earth

That we will cease to call them when we labour

Or ask them means of joy.

CAPA. Speak it Luasnad,

You are a wizard and know secret tongues.

[The baby cries.]

LUASNAD. All this life has been a hurtful game

Played out by steps of anguish. Every beast

Is bred with fearful torment in the womb

And bred by fearful torments in life-blood.

Yet by a bait of love the aimless gods

Have made us multitudes.

WIFE OF CAPA [keens]. You have born a child

In rain mists dark and wild.

WIFE OF LAINE. And weeping perished.

WIFE OF CAPA. Your dead breast is dry

And your dark babe will die.

WIFE OF LAINE. Unloved, uncherished.

LAINE. Come women, quit the dead.

When once these winds have fallen earth will dry.

WIFE OF LAINE [stopping and turning as they are going out].

Come Luasnad, bring your infant. You will perish

If you stay dreaming-

LUASNAD. Do not linger in your grieving

For he will perish though I dream or wake.

[She goes out.] 
LUASNAD. No se está sombrío más allá de la sombra que orilla el sudario de todos los hombres.

ESPOSA DE LAINE. ¿Es que hay una guerra entre los dioses y han vencido los del mar?

LUASNAD. No hay ninguna guerra.

Los dioses sólo laboran para vivir en paz sin oraciones.

\section{[Rompe otra ola.]}

CAPA. No digas más sacrilegios, Luasnad, podrían volverse en contra nuestra.

LUASNAD. He dejado de rezar, y no hay nada que vaya mejor con la ira que las plegarias.

ESPOSA DE LAINE. Diles

que, si quitan este agua de la tierra, dejaremos de recurrir a ellos en nuestros esfuerzos, y que tampoco les pediremos motivos de gozo.

CAPA. Dilo tú, Luasnad, que eres mago y conoces lenguas secretas.

[Llora el recién nacido.]

LUASNAD. Esta vida no ha sido más que un juego doloroso que ha ido avanzando con pasos de angustia. Todas las bestias se engendran con temibles tormentos en la matriz y con temibles tormentos en la sangre.

Sin embargo, por un simple cebo de amor, los dioses indiferentes nos han convertido en multitudes.

ESPOSA DE CAPA [llora lamentándose]. Has dado a luz a un niño en cortinas de agua, oscuras y feroces.

ESPOSA DE LAINE. Y el llanto murió.

ESPOSA DE CAPA. Tu pecho muerto está seco, y tu sombrío niño morirá.

ESPOSA DE LAINE. Sin amor, sin cuidados.

LAINE. Venid mujeres, dejad a los muertos.

En cuanto hayan calmado estos vientos, se secará la tierra.

ESPOSA DE LAINE [deteniéndose y dándose la vuelta conforme se van].

Vamos, Luasnad, trae a la criatura. Morirás, si te quedas ahí soñando-

LUASNAD. No persistáis en el lamento, porque, tanto si sueño como si despierto, morirá. 
I thought to build upon this isle of Banba

A tower of kings-

[Another wave breaks and a stone rolls down from the head of the mountain and strikes the infant. LUASNAD unfolds the green mantle. Wind and waves.]

The gods have pitied him,

We cannot reach the morning. All mankind

Will cease with dusk, and leave a sightless world

Where waves winds fish, wild forms that crowd the sea

Will please the curious fancies of the gods.

[A large wave breaks. Cries. WIFE OF LAINE runs in.]

WIFE OF LAINE. Look Luasnad, all the others are washed out

And drowning. As I climbed towards them came a wave

Curling across the boulders where they sat

That took them all as I would take some feathers

And threw them out to sea.

LUASNAD. Our time will come.

WIFE OF LAINA. I am so frightened, Luasnad.

LUASNAD. All things die;

I think the gods are grown old or sick

And for some bitter envy blast the world.

[A wave dashes over them.]

WIFE OF LAINE. Hold me Luasnad, I will fall and drown.

[They cling to each other.]

LUASNAD. Behind this rock we may sit thus till dawning.

WIFE OF LAINE. Where is your infant?

LUASNAD. A stone rolled down and killed him.

WIFE OF LAINE. Then bind your wife's green mantle round us both

The night is growing very cold and dark.

LUASNAD. I think a moon will waken if the night

Should let her light slip towards us.

[Comes down and binds the mantle round them.]

My wife and her dead baby have been washed

Out with the last great ebbing. We remain

Alone in the world of night.

WIFE OF LAINE. It would make

A strange new life if we came through this tempest 
Y yo que pensé levantar en esta isla de Banba una torre de reyes-

[Rompe otra ola, y de lo alto de la montaña cae rodando una piedra, que golpea al niño.

LUASNAD le quita el manto verde. Viento y olas.]

Los dioses han tenido piedad de él, no veremos la mañana. Toda la humanidad acabará en la penumbra, y dejará un mundo ciego en el que las olas, los vientos, los peces, las formas irracionales que pueblan el mar complacerán los curiosos caprichos de los dioses.

[Rompe una ola muy grande. Sollozos. La ESPOSA DE LAINE sale precipitadamente.]

ESPOSA DE LAINE. Escucha, Luasnad, los demás han sido arrebatados por las aguas y se ahogan. Cuando subía hacia ellos una ola llegó rodando por las rocas donde estaban sentados, y se los llevó a todos, igual que yo cogería unas plumas, y los lanzó al mar.

LUASNAD. Ya llegará nuestra hora.

ESPOSA DE LAINA. Estoy tan asustada, Luasnad.

LUASNAD. Todo muere;

creo que los dioses han envejecido o han enfermado, y por una amarga envidia destruyen el mundo.

[Una ola revienta por encima de ellos y los cubre.]

ESPOSA DE LAINE. Cógeme, Luasnad, voy a caerme y me ahogaré.

[Se abrazan con fuerza.]

LUASNAD. Tras esta roca podemos estar así sentados hasta el alba.

ESPOSA DE LAINE. ¿Y tu niño, dónde está?

LUASNAD. Cayó rodando una piedra, y lo mató.

ESPOSA DE LAINE. Entonces, envuélvenos en el manto verde de tu esposa, la noche es cada vez más fría y más oscura.

LUASNAD. Creo que despertará una luna si la noche deja que se deslice su luz hacia nosotros.

[Desciende y envuelve el manto en torno a ellos.]

Mi esposa y su niño muerto han sido arrastrados al mar con el último gran reflujo. Quedamos solos en el mundo de la noche.

- ESPOSA DE LAINE. Sería una vida nueva y extraña, si pasáramos esta tempestad 
And lived like Eve and Adam building up

A new mankind.

LUASNAD. Perhaps the gods have purpose

To fill the world with a new race more fit

Than man has been to bear the rage of life.

But woman they will kill us, man must die...

WIFE OF LAINE. There is the moon Luasnad, and three stars...

But in the other life, whence ghosts have wandered

Shall I find Laine out and Capa's wife

And talk about this tempest?

LUASNAD. We are like

These crowns of foam that gleam and flash with gold

And when our storm of passion has died out

A few old gods will just remember man.

WIFE OF LAINE. Hold me closer Luasnad, I am trembling-

I do not like to vanish and let live

The sea and stars without me.

LUASNAD. I can feel

Your heart beat and your blood-warmth underneath

Your thick wet habits.

WIFE OF LAINE. All the clouds have broken.

How white the waves look racing towards the sun!

And how deep black the troughs! Perhaps the gods

Have felt a little pity for my youth?

LUASNAD. There is no pity in the aimless gods

And they would mock me with your kind warm voice.

WIFE OF LAINE. It is hard to die.

LUASNAD. Women know more pain

When they give birth to children.

WIFE OF LAINE. I am young

And I have never yet conceived with child...

Why would the gods who made us now destroy?

LUASNAD. The gods have never made us. They have gotten

Our first grey seed upon the slime of earth

And have dealt with us as we deal with kine

Who know the one brother. We are one

With all this moon and sea white and the wind

That slays us. And our passions move when we die

Among the stars that wander or stand quiet 
y viviéramos como Eva y Adán construyendo una nueva humanidad.

LUASNAD. Quizá sea designio de los dioses llenar el mundo con una nueva raza, más adecuada que el hombre para soportar los embates de la vida. Pero, mujer, van a matarnos, el hombre debe morir..

ESPOSA DE LAINE. Ahí está la luna, Luasnad, y tres estrellas...

Pero, en la otra vida, de la que han venido, errabundos, los espíritus ¿encontraré a Laine y a la esposa de Capa, y hablaré de esta tempestad?

LUASNAD. Somos como esas crestas de espuma que brillan y destellan doradas, y cuando la tormenta de nuestra pasión se haya apagado unos cuantos dioses viejos apenas se acordarán del hombre.

ESPOSA DE LAINE. Cógeme más fuerte Luasnad, estoy temblandono quiero desaparecer y dejar que vivan sin mí el mar y las estrellas.

\section{LUASNAD. Siento} latir tu corazón y la calidez de tu sangre bajo tu mojado sayal.

ESPOSA DE LAINE. Todas las nubes se han quebrado. ¿Qué blancas parecen las olas en su carrera hacia el sol! ¡Y qué negros sus senos! ¿Querrán tener los dioses un poco de compasión de mi juventud?

LUASNAD. No hay misericordia en los dioses indiferentes, y se mofarían de mí con tu dulce y cálida voz.

ESPOSA DE LAINE. ¡Qué difícil se hace morir!

\section{LUASNAD. Las mujeres conocen un dolor mayor} cuando traen al mundo a un hijo.

ESPOSA DE LAINE. Soy joven, y nunca se ha concebido en mí una criatura..

¿Por qué iban a querer destruirnos los mismos dioses que nos han hecho?

LUASNAD. Los dioses jamás nos crearon. Tomaron nuestra primera simiente gris del limo de la tierra, y nos trataron como nosotros tratamos el ganado que reconoce al hermano. Somos uno con todo, la luna, el mar blanco y el viento que nos mata. $Y$ nuestras pasiones viajan cuando morimos a las estrellas que vagan o que están fijas 
In the great depths of night.

WIFE OF LAINE. Take your hand

Down from my bosom Luasnad.

\section{LUASNAD. I love you woman.}

WIFE OF LAINE. You would not shame the love of our dead consorts?

LUASNAD. The great west boulder of our peak has fallen

And with the next high river of the tide

Our death will reach us. There is not any hope.

WIFE OF LAINE. In this white moonlight perhaps the wind may die?

LUASNAD. You the fairest of all women, turn your lips.

The last strong man must perish,

Let me flash a last red flame of love

Across the brink of death, and shout defiance

Up to the aimless gods.

WIFE OF LAINE. Look on the eastern side,

A moonbeam has burst through and touched the sea.

LUASNAD. There is some shape behind the eastern dark,

A vessel all roofed over smeared with pitch.

WIFE OF LAINE. Are men within it?

LUASNAD. I think the gods have brought

From the dead country where the seas have end

Some new wild race to populate the wreck

Of this dead world.

WIFE OF LAINE. It may be Luasnad

The craft of some wily prophet of the east

Has built up there a little band of men

To make mankind eternal.

LUASNAD. If men steer,

The gods will guide this vessel with their hate

Till all her beams float down the endless sea.

WIFE OF LAINE. The clouds have come again and veiled the moon

And I can only hear the howl of waves.

LUASNAD. Maybe our frightened passions forged for us

This shadow on the waves.

WIFE OF LAINE. Does day come on

For I am very stiff and cramped with cold.

LUASNAD. Cling closer, I will warm you with my breath. 
en los grandes abismos de la noche.

ESPOSA DE LAINE.

Quita la mano

de mi pecho, Luasnad.

\section{LUASNAD. Te amo, mujer.}

ESPOSA DE LAINE. ¿No debería avergonzarte el amor de nuestros cónyuges muertos?

LUASNAD. La gran roca del oeste de nuestro pico ha caído, y con el próximo río del reflujo de la marea nos llegará la muerte. Ya no hay esperanza.

ESPOSA DE LAINE. Quizá muera el viento en esta luz de luna blanca

LUASNAD. Tú, la más bella de las mujeres, levanta los labios.

El último de los fuertes hombres debe morir, déjame que lance, como un postrer relámpago, una llamarada roja de amor por encima del abismo de la muerte, y que eleve un grito de desafío a los dioses indiferentes.

ESPOSA DE LAINE. Mira al este, un rayo de luna ha quebrado las nubes y toca el mar.

LUASNAD. Se ve una sombra más allá de la oscuridad del oriente, una nave cerrada con la cubierta calafateada.

ESPOSA DE LAINE. ¿Y hay hombres en ella?

LUASNAD. Me parece a mí que los dioses han traído del país de los muertos, del confín de los mares, una nueva raza bárbara para que pueble los restos del naufragio de este mundo muerto.

ESPOSA DE LAINE. Quizá sea, Luasnad, que las artes de algún profeta astuto del oriente han creado allí un pequeño grupo de hombres para que la humanidad sea eterna.

LUASNAD. Si son hombres los que la tripulan, los dioses con su odio guiarán la nave hasta que todo el maderamen flote disperso por el inmenso mar.

ESPOSA DE LAINE. Han vuelto las nubes, y velan la luna, y sólo oigo el aullido de las olas.

LUASNAD. Quizá nuestras aterrorizadas pasiones nos fraguaron esa sombra en las olas.

ESPOSA DE LAINE. ¿Avanza el día? estoy agarrotada, y me da calambres el frío.

LUASNAD. Pégate más a mí, te calentaré con mi aliento. 
WIFE OF LAINE. Remember Laine and the dead cold smile

That curled his lip.

LUASNAD. Dead men pass. There lives

One only life, one passion of one love,

One world wind sea, then one deep dream of death.

WIFE OF LAINE. I think that I will love you if earth dries,

But I am very fearful of the gods

And Laine in this tempest.

LUASNAD. Man's last high mood

Can pass above this passion of the seas

That moans to crush him. In each man's proper joy

The first high puissance that made live the gods

Lives on the earth and asks each stone for worship.

[Wave passes over them.]

WIFE OF LAINE. I am falling Luasnad!

LUASNAD. In this peril

The force that slays us is our own high glory.

[Wave sweeps them round and leaves them again beside the boulder.]

WIFE OF LAINE [crying out]. Oh Luasnad, must man perish? Spare me, gods!

LUASNAD. Heed not the gods. In this high passionate sea

Mere gods would perish-

WIFE OF LAINE. Ah! See the dark black vessel.

[They are swept off.] 
ESPOSA DE LAINE. Recuerda a Laine y la sonrisa fría de muerte que curvó su labio.

LUASNAD. Los muertos pasan. Sólo se vive una única vida, una pasión de un amor, un mundo, viento, mar, después, un hondo sueño de muerte.

WIFE OF LAINE. Creo que te amaré, si la tierra se seca, pero me dan mucho miedo los dioses y Laine en esta tempestad.

LUASNAD. El último ánimo sublime del hombre puede remontarse sobre esta pasión de los mares que gime por aplastarle. En el gozo propio de cada hombre la primera fuerza que hizo vivir a los dioses vive en la tierra, y le pide adoración a cada piedra.

[Una ola pasa por encima de ellos.]

ESPOSA DE LAINE. ¡Me caigo, Luasnad!

LUASNAD. En este gran peligro la fuerza que nos mata es nuestra gloria sublime.

[Una ola los arrastra y los deja de nuevo junto a la roca.]

ESPOSA DE LAINE [gritando]. ¿Oh, Luasnad, debe morir el hombre? ¡Perdonadme a mí, dioses!

LUASNAD. Olvídate de los dioses. En este alto mar apasionado hasta los dioses perecerían-

ESPOSA DE LAINE. ¡Ah! Mira la oscura nave negra.

[Son arrastrados al mar.] 